\title{
Production of Amidase and $\beta$-Lactamase by Bacteria
}

\author{
By R. J. HOLT AND G. T. STEWART \\ Queen Mary's Hospital for Children, Carshalton, Surrey
}

(Received 14 August 1963)

\begin{abstract}
SUMMARY
Fresh clinical isolates of Gram-positive and Gram-negative bacteria were tested for the production of $\beta$-lactamase and amidase. Techniques for identifying and studying the latter enzyme are described, in relation to its action upon penicillins and other substrates. Various commensal and pathogenic Gram-negative bacilli produce a 'pen-amidase' of relatively narrow specificity, though no species invariably produces it. A specific pen-amidase was not formed by the Gram-positive bacteria examined, though nonspecific amidases were present. Escherichia coli and paracolon bacilli produced pen-amidase more often than $\beta$-lactamase but the Klebsiella-aerogenes group did the reverse. Among other organisms, enzyme production was very variable but absence of either enzyme did not necessarily connote sensitivity of an organism to any penicillin. Administration of penicillin to a patient promotes colonization of the gut and oropharynx by $\beta$-lactamaseforming coliforms, but not of amidase-forming organisms. There is a strong association between resistance to the penicillins and formation of $\beta$-lactamase by an organism; with pen-amidase, the association is less strong. Neither enzyme accounts completely for bacterial resistance to the penicillins, even within any one species of organism, but the lower resistance of coliforms to ampicillin may be related to the lesser susceptibility of this derivative to amidase.
\end{abstract}

\section{INTRODUCTION}

Viewed collectively the various penicillins now available act upon a wide range of Gram-positive and Gram-negative bacteria but, unlike other drugs, their action is influenced by inactivating enzymes produced by some of these species. It is generally agreed that penicillinase acting in this way accounts for the resistance of Staphylococcus aureus to penicillin, but the extent to which inactivating enzymes explain the resistance of other organisms is much less certain, especially since it is now known that at least two penicillin-splitting enzymes can be formed. One is a $\beta$-lactamase (Pollock, 1961) acting upon the lactam ring of the molecule. The other is an acylase (English, McBride \& Huang, 1960) or amidase (Batchelor, Chain, Richards \& Rolinson, 1961) acting at the peptide linkage of the prosthetic group. Apart from the resistance of individual bacteria, formation of penicillinase by commensal or collateral organisms may interfere with the action of penicillin upon the target organism. In the present work, we studied the production of inactivating enzymes by pathogenic and commensal organisms isolated from human sources. 


\section{METHODS}

The coliform and other organisms used in these studies were isolated from routine specimens submitted to the bacteriological laboratory. Each organism was titrated in broth in inocula of about $10^{7}$ organisms $/ \mathrm{ml}$. against increasing concentrations of various penicillins over an unusually wide range of concentrations (1-500 $\mu \mathrm{g} . / \mathrm{ml}$.) so that the limited sensitivity of some strains could be detected.

Penicillinase ( $\beta$-lactamase) was detected in four ways: (i) by bore-hole assay of bacteria-free filtrates of broth containing subinhibitory concentrations of drug, after growth of the organism; (ii) by adding whole-cell sediments from these cultures to solutions of the penicillins, which were then assayed against controls after $\mathbf{1 ~ h r}$ at $37^{\circ} \mathrm{C}$; (iii) by the membrane-plate technique, in which various penicillins were

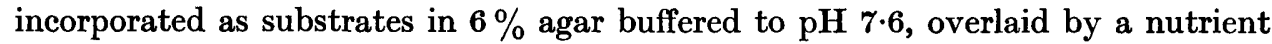
cellulose-acetate membrane upon which coliform organisms under test were inoculated in marked positions; after overnight incubation, the membranes were removed and the plates flood-inoculated with a suspension of indicator organisms (Staphylococcus aureus, NCTC 6571 (Oxford) or Sarcina lutea NCTC 8340) which grew, after further incubation, only in sites where the penicillin had been destroyed; these methods have been described elsewhere (Stewart, Coles, Nixon \& Holt, 1961; Holt \& Stewart, 1963); (iv) by applying the hydroxylamine method (see below) to detect disruption of the lactam ring.

\section{Techniques for the detection of amidase}

Use of differential penicillin substrates. The membrane-plate technique mentioned above (iii) was adapted by using 6-aminopenicillanic acid (6-APA) and penicillin G as substrates in the agar layer. Since it was unaffected by amidase 6-APA retained its activity and inhibited the indicator organism on further incubation after removal of the membrane; whereas penicillin $\mathrm{G}$ was de-acylated to 6-APA but in an ineffective concentration at which the indicator organism grew freely (Pl. 1, figs. 1, 2). When a $\beta$-lactamase was present, both substrates were inactivated; hence, by this test alone, amidase could not be detected in the presence of $\beta$-lactamase. It was necessary in this adaptation of the membrane-plate technique to use different indicator organisms in order to allow for the difference in intrinsic activity of each substrate. The Oxford staphylococcus (NCTC 6571) was inhibited in $6 \%$ agar at $\mathrm{pH} 7 \cdot 6$ by low concentrations $(<\mathbf{0} \cdot \mathbf{1} \mu \mathrm{g} . / \mathrm{ml}$.) of several therapeutically used penicillins (penicillin $\mathrm{G}$, penicillin $\mathrm{V}$, ampicillin) but withstood 6-APA at 50-100 $\mu \mathrm{g} . / \mathrm{ml}$. whereas Sarcina lutea, though inhibited by the penicillins within the same range, was much less resistant to 6-APA, being inhibited by $2 \mu \mathrm{g} . / \mathrm{ml}$. Hence the Oxford staphylococcus was suitable for detecting amidase-destruction of the penicillins, since these compounds could thereby be used over a range of substrate concentrations as high as $50 \mu \mathrm{g} . / \mathrm{ml}$., which excluded any possibility of inactivation by extraneous factors and yet left a reasonably high, though not inhibitory, residue of $30 \mu \mathrm{g} . / \mathrm{ml}$. 6-APA. For detecting destruction of 6-APA, however, Sarcina lutea was a more suitable indicator in view of its higher sensitivity to this compound. In some experiments, as described in the text, the residue left after test organisms had acted upon penicillin $\mathbf{G}$ was treated with phenylacetyl chloride to demonstrate resynthesis of benzylpenicillin and thereby prove that 
the residue was 6-APA. This was not done with all strains since additional methods of proof were also being used (Holt \& Stewart, 1964).

Use of other substrates. Theoretically, amidases should attack many substrates. To test the specificity of amidases of bacterial origin in this respect, leucylnaphthylamide and L-leucinamide were also used as substrates, the products of reaction being identified by colour changes and chromatography, as described in the experimental results. Crude aminopeptidase from a non-bacterial source (hog stomach, Sigma Chemical Co., 3500 Dekalb Street, St Louis 18, Mo., U.S.A.) was also used for purposes of comparison on these substrates and on penicillin.

Hydroxylamine method. The method of Ford (1947) was applied as follows. Washed bacteria were added to benzylpenicillin or 6 -APA $(100-500 \mu \mathrm{g} . / \mathrm{ml}$.) at $\mathrm{pH} 7 \cdot 0$ or $5 \cdot 6$, respectively, and kept at $37^{\circ}$ for $1 \mathrm{hr}$. After centrifugation, $0.5 \mathrm{ml}$. water, $6 \mathrm{ml}$. hydroxylamine reagent, $0 \cdot 25 \mathrm{ml} .5 \mathrm{~N}-\mathrm{H}_{2} \mathrm{SO}_{4}$ and $2 \mathrm{ml}$. ferric sulphate solution were added to $2 \mathrm{ml}$. samples of the supernatant fluids; $0.25 \mathrm{ml}$. $\mathrm{NaOH}$ and $0.25 \mathrm{ml}$. $5 \mathrm{~N}-\mathrm{H}_{2} \mathrm{SO}_{4}$ were added to $2 \mathrm{ml}$. blanks. Benzylpenicillin and 6-APA were used as standards, 6-APA being estimated (after amidase hydrolysis) by extracting with butyl acetate at $\mathrm{pH} \mathbf{2 \cdot 0}$ to remove residual benzylpenicillin. Readings were made in an S.P. 500 spectrophotometer (Unicam, Cambridge) at $495 \mathrm{~m} \mu$.

\section{RESULTS}

\section{Production of penicillin-inactivating enzymes by Escherichia coli}

Of 310 strains of Escherichia coli tested (Table 1), 125 (40\%) inactivated penicillin G but not 6-APA by the membrane-plate technique, and were therefore classified as specific amidase-producers. Thirty-four strains (12\%) inactivated both substrates and therefore produced $\beta$-lactamase; it is possible that some of these 34 strains also formed amidase for, in presence of $\beta$-lactamase, proof of an independent amidase cannot readily be obtained. About half the strains tested produced neither enzyme.

\section{Table 1. Production of amidase and $\beta$-lactamase by Escherichia coli}

\begin{tabular}{llllll} 
No. of strains tested & $\ldots$ & $\ldots$ & $\ldots$ & $\ldots$ & \multicolumn{1}{c}{310} \\
No. forming amidase & $\ldots$ & $\ldots$ & $\ldots$ & $\ldots$ & $125(40 \%)$ \\
No. forming $\beta$-lactamase & $\ldots$ & $\ldots$ & $\ldots$ & $\mathbf{3 4}(\mathbf{1 2} \%)$ \\
No. forming neither enzyme & $\ldots$ & $\ldots$ & $\ldots$ & $151(48 \%)$
\end{tabular}

These 310 strains had all been isolated from patients who were receiving no form of penicillin therapy; at the same time, a smaller number of strains isolated from the faeces or oropharynx of patients receiving penicillin was similarly tested (Table 2). The proportion of organisms forming $\beta$-lactamase was significantly higher in the latter group. There was no difference in amidase-production.

A group of 23 serotypes of Escherichia coli, isolated from children with gastroenteritis, was also examined (Table 3 ); here again, the proportions of amidaseformers and $\beta$-lactamase-formers did not differ significantly from the $\mathbf{3 1 0}$ miscellaneous strains. When these $\mathbf{3 1 0}$ strains, in turn, were grouped according to their sites of isolation, or whether they came from a lesion (e.g. infected urine, peritoneal pus) or from normal faeces, no differences in enzyme production were apparent. Tested by the hydroxylamine method (Table 4), amidase-forming coliform organisms did 
not attack the 6-APA nucleus, whereas $\beta$-lactamase-forming coliform organisms opened the lactam ring.

Independently of their source, coliform organisms which produced $\beta$-lactamase were all highly resistant to the various penicillins, requiring $500 \mu \mathrm{g} . / \mathrm{ml}$. or more for inhibition of growth, even with ampicillin, which is more active against Gramnegative bacilli than the other therapeutically used penicillins. Amidase-forming

\section{Table 2. Production of amidase and $\beta$-lactamase by Escherichia coli from patients receiving and not receiving penicillin therapy}

\begin{tabular}{|c|c|c|c|c|}
\hline \multirow{2}{*}{$\begin{array}{c}E . \text { coli } \\
\text { from patients }\end{array}$} & \multirow{2}{*}{$\begin{array}{c}\text { No. of } \\
\text { strains tested }\end{array}$} & \multicolumn{3}{|c|}{ No. of strains (observed/expected) forming } \\
\hline & & Amidase & $\beta$-lactamase & Neither enzyme \\
\hline Receiving a penicillin & $\mathbf{5 5}$ & $23 / 22$ & $17 / 8^{*}$ & $15 / 25$ \\
\hline Total & 365 & 120 & $5+10$ & $101 / 100$ \\
\hline Total & 365 & 148 & 51 & 166 \\
\hline
\end{tabular}

Table 3. Production of amidase and $\beta$-lactamase by 23 Escherichia coli serotypes isolated from children with gastro-enteritis

Minimal inhibitory concentration $(\mu \mathrm{g} . / \mathrm{ml})$ of

No. of strains (observed/expected) forming

$\begin{array}{lc}\text { Amidase } & 9 / 10^{*} \\ \beta \text {-lactamase } & 6 / 4^{*} \\ \text { Neither enzyme } & 8 / 9^{*} \\ \text { No. tested } & 23\end{array}$

$\begin{array}{cc}\text { Penicillin G } & \text { Ampicillin } \\ 500 & 50-100 \\ >500 & >500 \\ 50-200 & 10-100\end{array}$

* Difference not significant.

Table 4. Action of $\beta$-lactamase and amidase from Escherichia coli upon 6-aminopenicillanic acid (6-APA) (estimated by hydroxylamine method)

\begin{tabular}{|c|c|c|}
\hline Strain no. & $\begin{array}{r}\% \text { 6-APA } \\
\text { destroyed }\end{array}$ & Enzyme formed \\
\hline $\begin{array}{l}\text { c. } 11 \\
\text { C. } 48\end{array}$ & $\left.\begin{array}{l}79 \\
50\end{array}\right\}$ & $\beta$-lactamase \\
\hline $\begin{array}{l}\text { c. } 14^{*} \\
\text { c. } 33^{*}\end{array}$ & $\left.\begin{array}{l}\text { Nil } \\
\text { Nil }\end{array}\right\}$ & Amidase \\
\hline $\begin{array}{l}\text { c. } 256 \\
\text { c. } 257\end{array}$ & $\left.\begin{array}{l}\text { Nil } \\
\text { Nil }\end{array}\right\}$ & None \\
\hline
\end{tabular}

* These strains and two others have been accepted by the Department of Scientific Research (National Collection of Industrial Bacteria), Torry, Aberdeenshire, with reference numbers as follows: $E$. coli type $1:$ c. $14=$ NCIB $9464 ;$ c. $15=$ NCIB $9465 ;$ c. $33=$ NICB $9466 ;$ c. $48=$ NCIB 9472.

strains were less resistant to ampicillin (Tables 3 and 5), though highly resistant to penicillin G. Strains forming neither enzyme were much more readily inhibited, especially by ampicillin. Fifty-six strains were tested simultaneously against 5 different penicillins. This showed (Table 6) that there were some further differences between these representative penicillins, both as inhibitors and as substrates: in most instances, ampicillin was less vulnerable to amidase than penicillins $\mathrm{G}$ and $\mathrm{V}$, 
but was susceptible to the amidase of a minority of strains against which it was much less inhibitory; methicillin withstood hydrolysis by two $\beta$-lactamase strains, but was susceptible to that enzyme from another strain; organisms which formed neither enzyme were more readily inhibited by all the penicillins, but only ampicillin, penicillin $\mathrm{G}$ and penicillin $\mathrm{V}$, in that order, were sufficiently inhibitory for therapeutic purposes and, even then, were sometimes borderline.

Table 5. Relationship between resistance to penicillins and formation of enzymes by Escherichia coli (134 strains)

Minimal inhibitory concentration

\begin{tabular}{|c|c|c|c|c|}
\hline \multicolumn{2}{|c|}{$(\mu \mathrm{g} . / \mathrm{ml})}$. & \multirow{2}{*}{$\begin{array}{l}\text { No. of } \\
\text { strains }\end{array}$} & \multicolumn{2}{|c|}{ Production of } \\
\hline Penicillin G & Ampicillin & & Amidase & $\beta$-lactamase \\
\hline 50-200 & $5-100$ & 83 & $\mathbf{0}$ & $\mathbf{0}$ \\
\hline$>500$ & $50-200$ & 36 & 36 & $\mathbf{0}$ \\
\hline$>500$ & $>500$ & 15 & See text & 15 \\
\hline
\end{tabular}

Table 6. Inactivation of various penicillins by 56 strains of Escherichia coli in relation to minimal inhibitory concentrations

Inactivation ( + or - ) and minimum inhibitory concentration ( $\mu \mathrm{g} . / \mathrm{ml}$.$) of$

$\begin{array}{lcccccc}\text { Enzyme activity } & \text { No. tested } & \text { Penicillin G } & \text { Penicillin V } & \text { Methicillin } & \text { Cloxacillin } & \text { Ampicillin } \\ \text { Amidase } & \mathbf{1 6} & +(>\mathbf{5 0 0}) & +(>500) & -(>500) & -(>500) & -(20-200) \\ \text { Amidase } & 4 & +(>500) & +(>500) & -(>500) & -(>500) & +(>500) \\ \beta \text {-lactamase } & 2 & +(>500) & +(>500) & -(>500) & \pm(>500) & +(>500) \\ \beta \text {-lactamase } & 1 & +(>500) & +(>500) & +(>500) & +(>500) & +(>500) \\ \text { Neither } & \mathbf{3 3} & -(20-100) & -(20-100) & -(\mathbf{2 0 0}) & -(200) & -(5-100)\end{array}$

The susceptibility of methicillin to the $\beta$-lactamase from one coliform organism clearly required further investigation. This was done by performing the same tests on 250 unselected strains of Escherichia coli, of which 22 formed a $\beta$-lactamase active against penicillin $\mathrm{G}$ and 6 -APA. With 4 strains, this $\beta$-lactamase also inactivated $200 \mu \mathrm{g} . / \mathrm{ml}$. methicillin and $50 \mu \mathrm{g} . / \mathrm{ml}$. cloxacillin. This meant either that the $\beta$-lactamase from these strains was different from the usual coliform $\beta$-lactamase, or that an amidase was acting concurrently. To test the latter possibility, $50 \mu \mathrm{g} . / \mathrm{ml}$. methicillin and 10 or $50 \mu \mathrm{g} . / \mathrm{ml}$. cloxacillin were exposed to amidase from coliform organisms grown on membranes, and then to $\beta$-lactamase from various sources (coliform organisms, Staphylococcus aureus and Bacillus cereus 5 в). In each case, both compounds were destroyed. When tested by the same procedure in different order, i.e. $\beta$-lactamase followed by amidase, neither compound was destroyed.

\section{Action of coliform amidase on other substrates}

All the coliform organisms listed above were tested also for activity against $l$-leucyl- $\beta$-naphthylamide on the assumption that amidase would liberate a naphthalene residue by attacking the peptide linkage in this substrate. Membranes were impregnated with $1 \%$ substrate solution and laid on nutrient agar; they were then heavily inoculated with coliform organisms from solid cultures and kept at $37^{\circ}$ for 
$2 \mathrm{hr}$, after which the membranes were removed. A drop of saturated aqueous diazonium dye (Fast blue B) was added to the reverse sides. With all 310 strains tested, addition of the dye produced a blue colour, intensified by treatment with 0.01 M-copper sulphate solution. This substrate was therefore susceptible to amidases from all coliform organisms, independently of the ability of some of these organisms

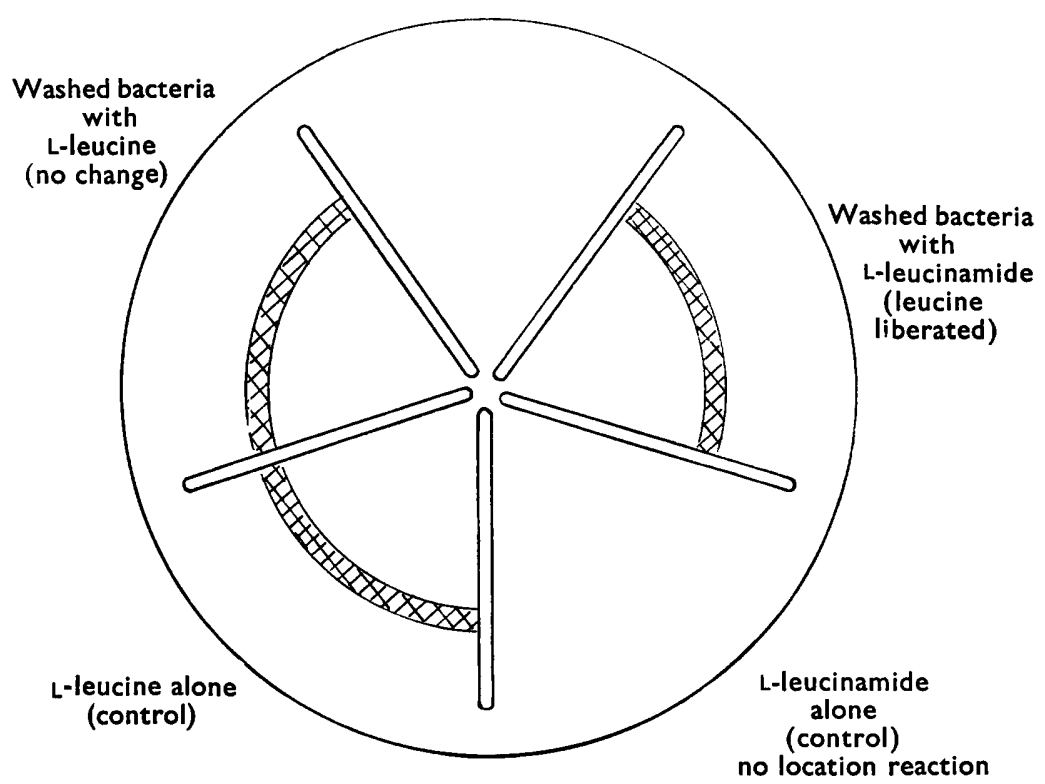

Fig. 1. Paper chromatography (Kawerau jar) showing effect of coliform organism c. 14 upon leucinamide as substrate. Washed bacteria and/or buffered substrate were applied at the apices of the divided paper segments. Leucine was liberated from the substrate by amidase formed by the bacteria.

to form a specific amidase, active against the penicillins as substrates. Staphylococcus aureus and many other organisms also attacked leucyl-naphthylamide, independently of their ability to produce any form of penicillinase. Conversely, this compound, in common with penicillin G but not 6-APA, was susceptible to the enzyme complex present in crude aminopeptidase from intestinal mucosa, proving that this enzyme-complex could behave as an amidase.

The locus of action of the amidase was then investigated by adding washed coliform organisms to L-leucinamide (0.05\%, 0.1\%, w/v). After $2 \mathrm{hr}$ at $37^{\circ}$ filtrates were applied to Whatman no. 1 paper for chromatography, as follows (by vol.): (a) two-dimensional run in ethanol 40 +butanol 40 + water $20+$ propionic acid 8 , followed by acetone 40 +water 20 + dicyclohexylamine 8 as solvents; $(b)$ onedimensional run on segmented paper in a Kawerau jar, using butanol 40 + acetone 40 + water 20 +dicyclohexylamine 8 as solvent. In each case the papers were developed in $0 \cdot 2 \%(\mathrm{w} / \mathrm{v})$ ninhydrin in acetone. All coliform organisms tested by this method liberated free leucine from the substrate (identified by $\mathbf{R}_{F}$ value and colour; (Fig. 1)), though many other organisms did not do so.

These results showed that amidase was present in all the coliform organisms as an 
enzyme complex of low specificity presumably capable of attacking $\mathrm{C}: \mathrm{N}$ or $\mathrm{CO}: \mathrm{NH}$ linkages in different loci. When penicillins were used as substrates, it was therefore necessary to prove directly that the $\mathrm{CO}: \mathrm{NH}$ linkage was attacked, leaving 6-APA as the principal residue. This was done by saturating $8 \mathrm{~cm}$. disks of Whatman no. 1 paper with penicillin $\mathrm{G} 200 \mu \mathrm{g}$. $/ \mathrm{ml}$., $200 \mu \mathrm{g}$. $/ \mathrm{ml}$. penicillin $\mathrm{V}$ and $100 \mu \mathrm{g}$. $/ \mathrm{ml}$. 6-APA. These were laid on $6 \%$ agar and covered by nutrient cellulose-acetate membranes, each of which was heavily inoculated at 4 marked points with a penicillin-amidaseforming coliform organism; a further set similarly treated was inoculated with a coliform organism which did not form penicillin-amidase. After overnight incubation the membranes were removed. Each of the underlying drug-loaded papers, into which any enzyme formed had meanwhile diffused, was then divided into halves. One half was sprayed with aqueous sodium bicarbonate $(5 \%, w / v)$, then with phenylacetylchloride, then with sodium bicarbonate again. The two halves were then placed in sterile Petri dishes and covered with $10 \mathrm{ml}$. melted agar at $60^{\circ}$ incorporating a light inoculum $\left(10^{5}\right.$ cocci $/ \mathrm{ml}$.) of Staphylococcus aureus NCTC 6571 as indicator organism. The dishes were then incubated overnight (Pl. 1, figs. 3, 4). On the penicillin $\mathbf{G}$ (and V) plate, the lower sprayed half showed inhibition of indicator organisms over the marked point (4), whereas the unsprayed half showed growth at points (1) and (2), corresponding to the positions of de-acylation by the penicillin-amidaseforming coliform organism. This meant that an active benzylpenicillin had been resynthesized in the sprayed paper from the residue left after the action of the coliform enzyme at point (4) and that the said residue was therefore 6-APA. When 25,000 units $\beta$-lactamase/ml. from Bacillus cereus 5 B were added to the sprayed paper before covering it with melted agar and indicator organism, growth was not inhibited at the marked point (3), showing that the substance at point (4) resynthesized at alkaline $\mathrm{pH}$ from the 6-APA residue was a benzylpenicillin. With the 6-APA plate (same figure) growth occurred over the whole of the unsprayed half of paper, since the concentration therein was subinhibitory, but was inhibited over the sprayed half by synthesis of benzylpenicillin except where ( $\mathrm{Pl}$. 1, fig. 3, point 3) $\beta$-lactamase had been applied.

De-acylation and resynthesis of penicillins $\mathrm{G}$ and $\mathrm{V}$ was similarly demonstrated with two other coliform organisms which likewise did not attack 6-APA, but not with coliform organisms which were inactive against these penicillins in the membrane plate technique; this therefore appeared to be a valid screening test for the presence of amidase as well as $\beta$-lactamase.

\section{Production of enzymes by other Gram-negative bacteria}

A total of 126 strains of various species was tested (Table 7). Amidase active against penicillin was produced by 29 , including some strains of paracolon bacilli, Klebsiella-aerogenes, Proteus, Shigella and Pseudomonas pyocyanea. $\beta$-Lactamase was formed by $\mathbf{2 2}$ organisms, including the majority of strains from the Klebsiellaaerogenes group, and occasional strains of paracolon bacilli, Proteus and $P$. pyocyanea. Of the 126 strains tested, 75 (including all strains of Salmonella and Bacteroides) produced neither enzyme. When tested against L-leucyl- $\beta$-naphthylamide as substrate, all 126 strains liberated a naphthalene residue which reacted with the diazonium dye. Leucinamide was decomposed by some strains of Proteus, but free leucine was not a product of this reaction. 
Table 7. Production of amidase and $\beta$-lactamase by various Gram-negative bacteria

\begin{tabular}{|c|c|c|c|c|}
\hline \multirow[b]{2}{*}{ Organism } & \multirow[b]{2}{*}{ No. tested } & \multicolumn{3}{|c|}{ No. producing } \\
\hline & & Amidase & $\beta$-lactamase & Neither enzyme \\
\hline B. paracolon & 17 & 9 & 2 & 6 \\
\hline 'Klebsiella-aerogenes' & 18 & 2 & 12 & 4 \\
\hline Proteus mirabilis & 25 & 5 & 4 & 16 \\
\hline P. vulgaris & 4 & 0 & 1 & 3 \\
\hline P. morganii & 19 & 4 & 1 & 14 \\
\hline P. rettgeri & 1 & 1 & $\mathbf{0}$ & 0 \\
\hline Shigellas & 7 & 5 & o & $\mathbf{2}$ \\
\hline Salmonellas & 18 & 0 & o & 18 \\
\hline Pseudomonas pyocyanea & 9 & 3 & 2 & 4 \\
\hline Bacteroides* & 8 & 0 & $\mathbf{0}$ & 8 \\
\hline Escherichia coli (for comparison) & 310 & 125 & 34 & 151 \\
\hline
\end{tabular}

Table 8. Production of amidase and $\beta$-lactamase by Gram-positive bacteria

\begin{tabular}{|c|c|c|c|c|}
\hline \multirow[b]{2}{*}{ Organism } & \multirow[b]{2}{*}{ No. tested } & \multicolumn{3}{|c|}{ No. producing } \\
\hline & & Amidase & $\beta$-lactamase & Neither enzyme \\
\hline Staphylococcus aureus & 43 & $\mathbf{0}$ & 28* & 15 \\
\hline S. albus & 14 & 0 & 6 & 8 \\
\hline Streptococcus faecalis & 21 & $\mathbf{0}$ & $\mathbf{0}$ & 21 \\
\hline S. hominis & $\mathbf{3}$ & o & $\mathbf{0}$ & $\mathbf{3}$ \\
\hline S. viridans & 6 & $\mathbf{0}$ & $\mathbf{0}$ & 6 \\
\hline Clostridia† & 11 & 0 & $\mathbf{0}$ & 11 \\
\hline Lactobacilli $\dagger$ & 4 & $\mathbf{0}$ & $\mathbf{0}$ & 4 \\
\hline \multicolumn{3}{|c|}{ * Including 11 methicillin-resistant strains } & \multicolumn{2}{|c|}{$\uparrow$ Tested anaerobically. } \\
\hline
\end{tabular}

None of 102 strains tested produced a penicillin-amidase (Table 8). Twenty-eight strains of Staphylococcus aureus and 6 of $S$. albus formed $\beta$-lactamase, including 11 which were resistant to all forms of penicillin. None of the other organisms formed $\beta$-lactamase, but all of them split the leucyl-naphthylamide substrate.

\section{DISCUSSION}

Among the various factors responsible or thought to be responsible for resistance of bacteria to penicillin, production of penicillinase has long been known (Abraham \& Chain, 1940; Bondi \& Dietz, 1944). One form of this enzyme, now known to be a $\beta$-lactamase (Pollock, 1961), is undoubtedly responsible for the resistance of Staphylococcus aureus to penicillin $\mathrm{G}$ (Barber, 1947); but it does not explain the high resistance commonly encountered among coliform organisms and other Gram-negative bacilli (Stewart, 1947; Chain, Florey \& Jennings, 1949), nor does it explain the resistance of some staphylococci to methicillin (Stewart, 1961; Barber \& Waterworth, 1962; Stewart \& Holt, 1963). The work of Sakaguchi \& Murao (1950) suggested that some organisms formed an enzyme capable of attacking benzylpenicillin at another locus; this was later shown (Batchelor et al. 1959) to be an amidase capable of liberating 6-aminopenicillanic acid, with lesser antibacterial activity, from penicillin $G$ or 
penicillin V. Since then, other workers have shown that acylase or amidase is produced by coliform organisms (English, McBride \& Huang, 1960).

The results reported here show that a variety of human commensal and pathogenic Gram-negative bacilli produce a specific amidase, acting at the linkage of the prosthetic side-chain to the $\mathrm{NH}$ group of 6-aminopenicillanic acid, though no single species invariably produces it. Escherichia coli and paracolon bacilli produce amidase more often than $\beta$-lactamase, but many strains produce neither enzyme, even under the conditions of inducement by presence of substrate which the membrane-plate technique provides. Organisms of the Klebsiella-aerogenes group, on the other hand, produce $\beta$-lactamase more often than amidase. Pseudomonas pyocyanea can produce either enzyme. Strains of Proteus vary considerably, but the most resistant type, $P$. morgani, does not appear to form inactivating enzymes more frequently than the less resistant $\boldsymbol{P}$. vulgaris and $\boldsymbol{P}$. mirabilis. Salmonellas appear to be unable to form either enzyme. Penicillin-amidase production was not detected in various species of Gram-positive bacteria.

It is evident that the administration of penicillin favours selective survival or colonization in the gut or oropharynx of coliform organisms which can form $\beta$-lactamase. There is however no evidence that amidase-forming coliform organisms behave similarly, even in patients in whom heavy colonization of the oropharynx occurred during penicillin therapy in the present survey. Pathogenic coliform organisms do not differ from those present commensally in the faeces in the production of either enzyme.

There is a close relationship between enzyme-production by Escherichia coli and resistance to some of the penicillins. Strains which form $\beta$-lactamase are invariably resistant to more than $500 \mu \mathrm{g} . / \mathrm{ml}$. of any penicillin, though methicillin can withstand inactivation by the otherwise typical enzyme formed by the majority of these strains; this does not however mean that such organisms are in the slightest degree sensitive to methicillin. Amidase-forming strains are resistant to penicillins $G$ and $\mathrm{V}$, methicillin and cloxacillin, but the majority of strains in the present series are unable to inactivate ampicillin and are more sensitive to this compound; here again, a paradox is evident, for this amidase does not readily inactivate methicillin or cloxacillin, though the organism is still highly resistant. When these compounds are subjected to high concentrations of both enzymes, destruction occurs, but this could only be demonstrated by a two-stage technique which may or may not bear any relation to natural happenings.

The present results therefore confirm and extend those of English, McBride \& Huang (1960) and Sabath \& Finland (1963). The former workers showed that many coliform organisms form acylase or amidase capable of inactivating various penicillins; the latter group showed that 26 out of 55 Gram-negative bacteria inactivated one or more of 5 penicillins, but they did not try to identify amidase. The action of this enzyme against ampicillin was studied by Ayliffe (1963) who reported that it was not formed by any of 109 strains of coliform organisms, including 49 which were resistant to ampicillin. He concluded that, if ampicillin was inactivated, this was attributable to $\beta$-lactamase. Our results do not entirely support these conclusions; we would agree that amidase does not always inactivate ampicillin and that high coliform resistance to this compound is associated with production of $\beta$-lactamase, but moderate degrees of resistance $(50-200 \mu \mathrm{g} . / \mathrm{ml}$.) were found among amidase- 
forming strains which were frequently encountered in our series, unlike his. The difference in this respect may be one of technique. Ayliffe identified amidase by reconverting the degraded substrate to benzylpenicillin, whereas we relied upon the use of different substrates in the screening procedure, and then tested the products of degradation where applicable by resynthesis and hydroxylamine reactivity. Ideally, the products of inactivation should be examined as well as the inactivating process in all such experiments.

Penicillinases from Gram-negative as well as Gram-positive bacteria were examined by Smith \& Hamilton-Miller (1963). They found, and we would agree, that the $\beta$-lactamase from different Gram-negative bacteria varied in their pattern of specificity and did not show the inducibility characteristic, for example, of the enzymes from staphylococci. Amidase as well as $\beta$-lactamase may fall into this category. The susceptibility of substrates like leucylnaphthylamide and leucinamide to enzymes from many bacterial species shows that amidases are widespread, perhaps as part of complex aminopeptidases which practically all free-living microorganisms must possess. Only a few of these amidases attack penicillins, despite the presence in all therapeutic penicillins of a theoretically-vulnerable $\mathrm{CO}: \mathrm{NH}$ linkage. Amidase is obviously a less powerful enzyme which operates effectively within a limited pH range and, though active against penicillin G, may not inactivate closely-related derivatives of 6-aminopenicillanic acid such as ampicillin. In view of this narrow specificity of penicillin-splitting amidase, the enzyme should be referred to more precisely in terms of the substrate, as is done with esterases; for ready reference, the term 'penamidase' might be appropriate, to distinguish the enzyme from those others possessed by many bacteria which attack $\mathrm{C}: \mathrm{N}$ or $\mathrm{CO}: \mathrm{NH}$ linkages.

Acknowledgement is made gratefully to the following: Miss P. M. Harrison, Mr M. Chapman and Mrs J. White for technical assistance; Beecham Research Laboratories, Brentford, and Connaught Research Laboratories, University of Toronto, for supplies of different penicillins.

\section{REFERENCES}

Abraham, E. P. \& Cain, E. B. (1940). An enzyme from bacteria able to destroy penicillin. Nature, Lond. 146, 837.

Abraham, E. P. \& Newton, G. G. F. (1961). New penicillins, cephalosporin C and penicillinase. Endeavour, $20,92$.

Ayliffe, G. A. J. (1963). Ampicillin inactivation and sensitivity of coliform bacilli. J. gen. Microbiol. 30, 339.

Barber, M. (1947). Coagulase positive staphyloccocci resistant to penicillin. J. Path. Bact. 59, 373.

Barber, M. \& Waterworth, P. M. (1962). Antibacterial activity of the penicillins. Brit. med.J. i, 1159.

Batchelor, F. R., Doyle, F. P., Nayler, J. H. C. \& Rolinson, G. N. (1959). Synthesis of penicillin; 6-aminopenicillanic acid in penicillin fermentations. Nature, Lond. 183, 257.

Batchelor, F. R., Chain, E. B., Richards, M. \& Rolinson, G. N. (1961). Formation of 6-aminopenicillanic acid from penicillin by enzyme hydrolysis. Proc. roy. Soc. B, 154, 522 . 
Bondi, A. \& Dietz, C. C. (1944). Production of penicillinase by bacteria. Proc. Soc. exp. Biol., N.Y. 56, 132.

Chain, E. B., Florey, H. W. \& Jennings, M. A. (1949). In Antibiotics, by Florey et al., pp. 1090-1100. Oxford University Press.

English, A. R., McBride, T. C. \& Huang, H. T. (1960). Microbial resistance to penicillins as related to penicillinase or penicillin amidase activity. Proc. Soc. exp. Biol., N.Y. 104, 547.

Ford, S. H. (1947). Hydroxylamine method for determining penicillins. Industr. Engng Chem. (Anal.), 19, 1004.

Holt, R. J. \& Stewart, G. T. (1963). Techniques for the rapid and sensitive detection of penicillinase. J. clin. Path. 16, 263.

Holt, R. J. \& Stewart, G. T. (1964). Penicillin amidase from coliforms: its extraction and some characteristics. Nature, Lond. 201, 824.

Pollock, M. R. (1961). The measurement of the liberation of penicillinase from Bacillus subtilis. J.gen. Microbiol. 26, 129.

Rolinson, G. N. \& Stevens, Shirley (1961). Microbiological studies on a new broad spectrum penicillin ('Penbritin'). Brit. med.J. ii, 191.

Sabath, L. \& Finland, M. (1963). Inactivation of some semisynthetic penicillins by Gramnegative bacilli. J. Bact. 85, 314.

Sakaguchi, K. \& Murao, S. (1950). A preliminary report on a new enzyme 'penicillin amidase'. J. agric. Chem. Soc. Japan 23, 411.

Smith, J. T. \& Hamilton-MinLer, J. M. T. (1963). Difference between penicillinases from Gram-positive and Gram-negative bacteria. Nature, Lond. 197, 976.

Stewart, G. T. (1947). Studies on the effect of penicillin upon Gram-negative bacteria. Penicillin-sulphonamide synergy. J. Hyg., Camb. 45, 282.

Stewart, G. 'T. (1961). Changes in sensitivity of staphylococci to methicillin. Brit. med.J. i, 863.

Stewart, G. 'T., Coles, H. M. 'T., Nixon, H. H. \& Holt, R. J. (1961). 'Penbritin': an oral penicillin with broad-spectrum activity. Brit. med. J. ii, 200.

Stewart, G. 'T. \& Holt, R. J. (1963). Evolution of natural resistance to the newer penicillins. Brit. med. J. i, 308.

Tosoni, A. L., GLass, D. G. \& Goldsmith, L. (1958). Crystalline $p$-aminobenzyl-penicillin: preparation and some properties. Biochem.J. 69, 476.

\section{EXPLANATION OF PLATE}

Figs. 1, 2. Membrane plate technique for detection of amidase and $\beta$-lactamase by growing cultures or suspensions of bacteria (coliform organisms). Appearance of plate after removal of membrane, showing growth of indicator organisms at sites of destruction of substrate (see text).

Fig. 1. Substrate penicillin $\mathrm{G}(50 \mu \mathrm{g} . / \mathrm{ml}$.)

Fig. 2. Substrate 6-APA $(100 \mu \mathrm{g}$. $/ \mathrm{ml}$.$) . 1,2,4,5,6,7,8$, Destruction of penicillin $\mathrm{G}$ but not 6-aminopenicillanic acid (6-APA) by amidase. 9, Destruction of penicillin $G$ and 6-APA by $\beta$-lactamase. 3, Destruction of neither.

Figs. 3, 4. Resynthesis of benzylpenicillin following action of amidase-forming bacteria. Sprayed paper technique (see text). The lower half of the paper in each plate was sprayed with phenylacetyl chloride.

Fig. 3. Substrate benzylpenicillin (penicillin G). Unsprayed: indicator organism killed except at points (1) and (2), where amidase-forming coliform organisms were inoculated on membrane. Sprayed: (4) No growth of indicator organism (resynthesis of benzylpenicillin). (3) Growth (resynthesized benzylpenicillin hydrolysed by addition of $\beta$-lactamase)

Fig. 4. Substrate 6-aminopenicillanic acid (6-APA). No inhibition of indicator organism. (4) No growth of indicator organism (synthesis of benzylpenicillin). (3) Growth (synthesized benzylpenicillin hydrolysed by addition of $\beta$-lactamase). 
Journal of General Microbiology, Vol. 36, No. 2

Plate 1
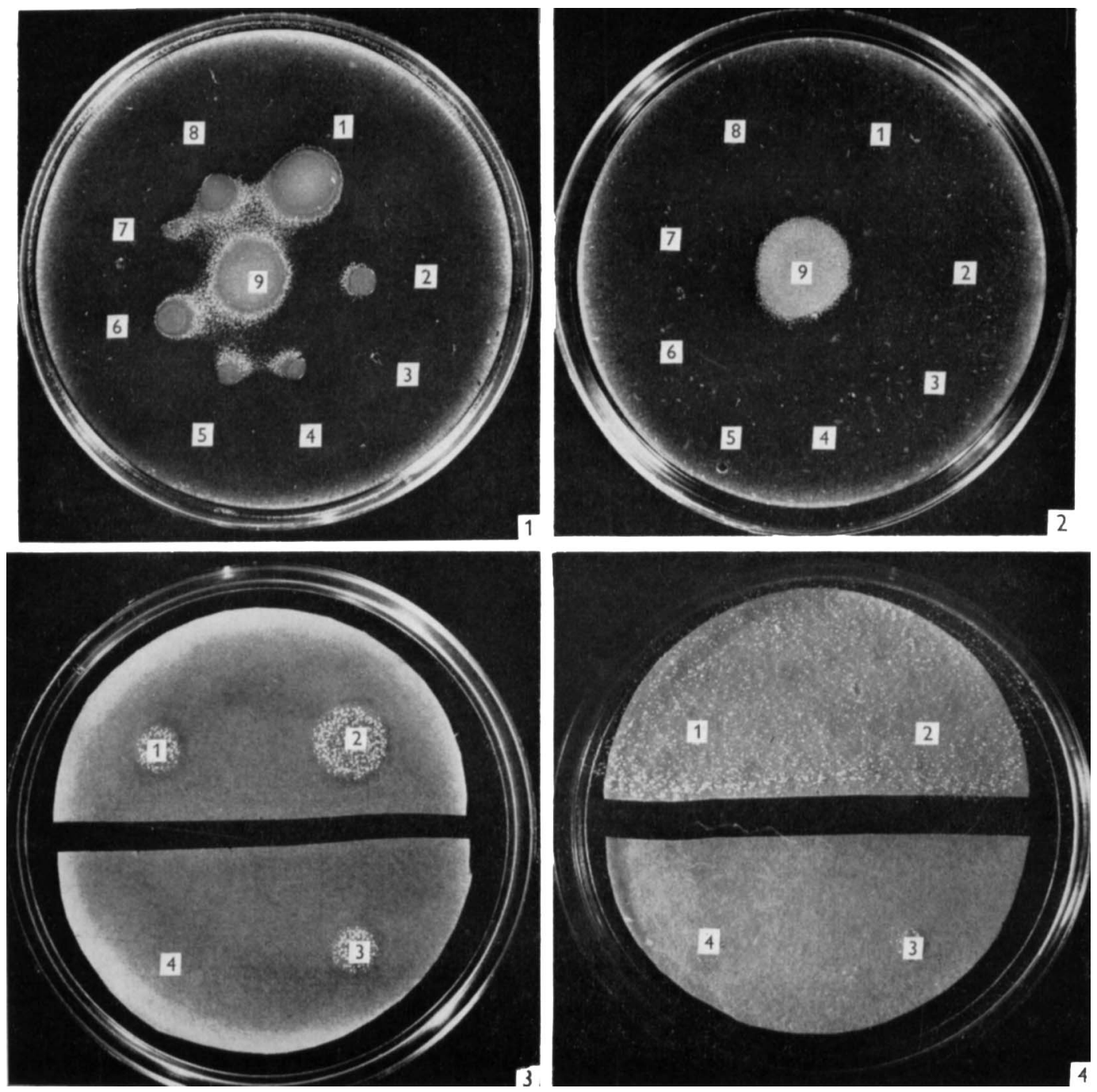